\title{
Identification and Characterization of the Huanglongbing Bacterium in Pummelo from Multiple Locations in Guangdong, P. R. China
}

\author{
X. Deng, Laboratory of Citrus Huanglongbing Research, Department of Plant Pathology, South China Agricultural \\ University, Guangzhou, P. R. China; J. Chen, Crop Diseases, Pests, and Genetics Research Unit, San Joaquin Valley \\ Agricultural Sciences Center, United States Department of Agriculture-Agricultural Research Service (USDA-ARS), \\ Parlier, CA; Z. Feng, Z. Shan, and H. Guo, Laboratory of Citrus Huanglongbing Research, Department of Plant \\ Pathology, South China Agricultural University; J. Zhu, Bureau of Science and Technology, Maoming, Guangdong, \\ P. R. China; H. Li, Laboratory of Citrus Huanglongbing Research, Department of Plant Pathology, South China Ag- \\ ricultural University; and E. L. Civerolo, Crop Diseases, Pests, and Genetics Research Unit, San Joaquin Valley Ag- \\ ricultural Sciences Center, USDA-ARS
}

\begin{abstract}
Deng, X., Chen, J., Feng, Z., Shan, Z., Guo, H., Zhu, J., Li, H., and Civerolo, E. L. 2008. Identification and characterization of the Huanglongbing bacterium in pummelo from multiple locations in Guangdong, P. R. China. Plant Dis. 92:513-518.

Huanglongbing (HLB, yellow shoot disease, ex. citrus greening disease), caused by Candidatus Liberibacter spp., is highly destructive to citrus production in Asia, Africa, and South America. Although primarily affecting sweet orange and mandarin, HLB has long been observed in pummelo in Guangdong Province, People's Republic of China; however, the disease in pummelo has received little research attention. Accordingly, it remains unclear how closely related the strains of $\mathrm{Ca}$. Liberibacter in pummelo are to those in other citrus species. In this study, the loci of $16 \mathrm{~S}$ rDNA, rplAJ ( $\beta$-operon of ribosomal protein), and an outer membrane protein (omp) gene were analyzed and characterized among strains of $\mathrm{Ca}$. Liberibacter in pummelo samples from six different locations in Guangdong. Sequence comparisons indicated that 'Candidatus Liberibacter asiaticus', but not ' $\mathrm{Ca}$. Liberibacter africanus' or ' $\mathrm{Ca}$. Liberibacter americanus', was exclusively associated with HLB symptoms in pummelo. The pummelo strains of ' $\mathrm{Ca}$. Liberibacter asiaticus' from Guangdong were highly homogeneous. Analyses of single-nucleotide polymorphisms in the omp locus showed that the Guangdong pummelo strains grouped with ' $\mathrm{Ca}$. Liberibacter asiaticus' strains from Thailand, Nepal, and an unspecified location in China but differed from the Philippine and China-Behai strains. Based on the sequence homogeneity at the omp locus, the history of pummelo culture and the means by which HLB is known to be spread, we believe that, likely, the pummelo strain of ' $\mathrm{Ca}$. Liberibacter asiaticus' recently was spread to pummelo in the study areas from infected sweet orange or mandarin trees by insect vectors or by propagation of pummelo infected elsewhere.
\end{abstract}

Additional keywords: Citrus grandis, $\beta$-operon

Huanglongbing (HLB, yellow shoot disease, ex. greening disease) is a destructive disease of citrus trees in Asia, Africa, and South America. The disease recently was found in Florida in pummelo (Citrus grandis (L.) Osbeck; 11). HLB first was reported in the Chaoshan area of Guangdong Province, People's Republic of China (PRC), and was identified by the yellow shoot symptoms, with symptoms seen mainly in mandarin (C. reticulata Blanco) and sweet orange (C. sinensis (L.) Osbeck). Symptoms also were seen in other

Corresponding authors: J. Chen and H. Li; E-mail: jichen@fresno.ars.usda.gov, hpli@scau.edu.cn

Accepted for publication 15 November 2007.

doi:10.1094/PDIS-92-4-0513

This article is in the public domain and not copyrightable. It may be freely reprinted with customary crediting of the source. The American Phytopathological Society, 2008.
Citrus spp., including pummelo (C. grandis (L.) Osbeck; 19). HLB is occasionally referred to as "yellow dragon disease." However, in the local Chaoshan dialect, "long" refers to "young shoots" rather than "dragon." Therefore, "Huanglongbing" means "yellow shoot disease" (19), and is characterized by yellowing of young foliar shoots, leaf mottling, and greening of mature fruit.

Jagoueix et al. (15) first named the etiological agent of HLB as Liberobacter, with the name changed later by Garnier et al. to Liberibacter (13). Based on signature sequences in the $16 \mathrm{~S}$ rDNA locus, three HLB bacterial species are now recognized: 'Candidatus Liberibacter asiaticus', found in Asia and elsewhere; ' $C a$. Liberibacter africanus', found in South Africa (15); and ' $\mathrm{Ca}$. Liberibacter americanus', found in Brazil (3,24). Because Ca. Liberibacter spp. are so far unculturable in artificial media, the bacteria are identified mainly through DNA-based methods, specifically the polymerase chain reaction (PCR). ' $\mathrm{Ca}$. Liberibacter americanus' is readily separated from ' $\mathrm{Ca}$. Liberibacter asiaticus' and ' $C a$. Liberibacter africanus' by PCR with the specific primer set GB1/GB3, which was designed from the $16 \mathrm{~S}$ rDNA locus (23). ' $\mathrm{Ca}$. Liberibacter asiaticus' and ' $\mathrm{Ca}$. Liberibacter africanus' are identified by primer sets OI1/OI2c and OA1/OI2c, which also were designed from the $16 \mathrm{~S}$ rDNA locus (16), and these two species can be differentiated by $X b a \mathrm{I}$ restriction digestion of the PCR amplification products. Hocquellet et al. (14) developed PCR primers from the sequence of the $r p l$ A-J region of ribosomal protein genes of the $\beta$ operon which produce amplicons of different sizes and allow differentiation of ' $\mathrm{Ca}$. Liberibacter asiaticus' and ' $\mathrm{Ca}$. Liberibacter africanus'. The outer membrane protein (omp) gene region is the third locus and is used to differentiate strains of ' $\mathrm{Ca}$. Liberibacter asiaticus' from different geographical locations by restriction enzyme fragment length polymorphisms (RFLPs; 1 ).

Due to high fruit quality and significant economic profits, demand for pummelo cultivars such as Shatianyou and Juhong is high in China. The current pummelo production area in Guangdong Province is over 30,000 ha. In the past decade, the incidence of HLB in pummelo has been increasing along with increased pummelo production. Identification and characterization of the pummelo HLB agent will provide important basic information for research and management of the disease.

The infectious nature of HLB from pummelo was demonstrated by graft transmission in 1995 by Deng et al. (10). An approximately 500-bp DNA fragment was detected in leaves from HLB-affected pummelo trees using primers from the $r p l \mathrm{~L}-r p o \mathrm{~B}$ region of the $\beta$-operon of ' $\mathrm{Ca}$. Liberibacter asiaticus' (6-8). Liao et al (18) reported a $16 \mathrm{~S}$ rDNA sequence (AY192576) from HLB from grapefruit (C. paradisi Macfad.) in Fujian. Yet, the annotation in the current version of GenBank database was $C$. grandis (L.) Osbeck, as cited by Teixeira et al (24) for phylogenetic analysis; therefore, it is unclear if 
sequence from $\mathrm{Ca}$. Liberibacter spp. from pummelo has been described. In all cases, only a single pummelo strain was analyzed. In this study, we identified and characterized the pummelo strains of $\mathrm{Ca}$. Liberibacter from different locations in Guangdong using currently available molecular tests. We examined the bacterial population in HLB-affected pummelo trees using the omp locus, which is known to differentiate ' $\mathrm{Ca}$. Liberibacter asiaticus' strains found in China, for the purpose of establishing a foundation of information for future HLB epidemiological studies.

\section{MATERIALS AND METHODS}

Plant materials. HLB symptomatic pummelo and sweet orange trees were identified in different areas of Guangdong Province, PRC (Fig. 1). Disease symptoms of leaf mottling and yellowing were observed in the field. Leaf samples were collected and shipped to the Huanglongbing Research Laboratory at the South China Agricultural University in Guangzhou. Upon arrival, the samples were stored at $4^{\circ} \mathrm{C}$ and processed within $48 \mathrm{~h}$. Samples from HLB-affected sweet orange trees maintained in the screenhouse or collected in the field from trees identified with typical HLB symptoms were used for DNA extraction to obtain positive controls. Leaves from asymptomatic pummelo trees in the screenhouse and in the field were used as a source of DNA for negative con- trols. In this study, HLB bacterial strains were defined by both the geographical location where they were collected and the host plant infected.

DNA extraction. Midribs of pummelo leaves were excised with a sterile razor blade. DNA was extracted using the cetyltrimethylammonium bromide (CTAB) method $(17,20)$. Briefly, $0.5 \mathrm{~g}$ of midribs was cut into small pieces with sterilized scissors, frozen with liquid nitrogen, then ground into powder with a mortar and pestle. A $2 \%$ CTAB buffer $(2 \mathrm{ml})$ was added and the mixture was transferred into a $1.5-\mathrm{ml}$ microcentrifuge tube and incubated in a water bath at $65^{\circ} \mathrm{C}$ for $30 \mathrm{~min}$ with occasional agitation. After extraction with a phenol:chloroform:iso-amyl alcohol solution (24:24:1), DNA was precipitated by the addition of $1 / 10$ volume of $3 \mathrm{M}$ sodium acetate ( $\mathrm{pH} 5.2)$ and 2 volumes of alcohol and was collected by centrifugation. The pellets were dissolved in $100 \mu \mathrm{l}$ of Tris-EDTA buffer ( $10 \mathrm{mM}$ Tris- $\mathrm{HCl}, 1$ mM EDTA, $\mathrm{pH}$ 8.0) with $0.5 \mu$ l of RNaseA $(10 \mathrm{mg} / \mathrm{ml})$ and incubated in a water bath at $37^{\circ} \mathrm{C}$ for $30 \mathrm{~min}$. The quality of the extracted DNA was evaluated by electrophoresis in a $1 \%$ agarose gel and visualized by transillumination with UV light after staining with ethidium bromide. DNA was stored at $-20^{\circ} \mathrm{C}$ for later use in Guangzhou or the United States.

PCR protocol. Primer sets used in this study are listed in Table 1 . In the labora- tory in PRC, PCR was carried out in a final volume of $25 \mu \mathrm{l}$ with a Perkin Elmer GeneAmp 2400 PCR System. The reaction mixture contained $2.5 \mu \mathrm{l}$ of $10 \times$ DNA polymerase buffer, $2 \mu \mathrm{l}$ of dNTPs $(2.5 \mathrm{mM}$ of each dNTP), $1 \mu \mathrm{l}$ each of the forward and reverse primers $(5 \mu \mathrm{M}), 1 \mu \mathrm{l}$ of DNA template, $0.2 \mu$ of $T a q$ DNA polymerase (5 $\mathrm{U} / \mu \mathrm{l}$; Shanghai Shenergy Biocolor BioScience and Technology Company, PRC), and $18.3 \mu \mathrm{l}$ of double-distilled $\mathrm{H}_{2} \mathrm{O}$. DNA amplification by PCR was performed as follows: reactions were preheated at $94^{\circ} \mathrm{C}$ for $5 \mathrm{~min}$; followed by 35 cycles of denaturation at $94^{\circ} \mathrm{C}$ for $1 \mathrm{~min}$, annealing at $56^{\circ} \mathrm{C}$ for $1 \mathrm{~min}$, and extension at $72^{\circ} \mathrm{C}$ for $2 \mathrm{~min}$; with a final extension at $72^{\circ} \mathrm{C}$ for $10 \mathrm{~min}$. Sterile deionized water and DNA of Xylella fastidiosa strains Dixon and Temecula-1 (Teme) were used as negative controls. Amplification products were evaluated by electrophoresis in $1 \%$ agarose gels and visualized by staining with ethidium bromide.

In the laboratory in the United States, PCR in $25 \mu \mathrm{l}$ was carried out using the TaKaRa taqTM (Hot Start Version) kit (Takara Bio Inc., Seta 3-4-1; Otsu, Shiga, Japan). The reaction mixture contained 2.5 $\mu \mathrm{l}$ of $10 \times$ DNA polymerase buffer, $2.5 \mu \mathrm{l}$ of dNTPs (2.5 mM each dNTP), $0.5 \mu \mathrm{l}$ each of the forward and reverse primers (10 $\mu \mathrm{M}), 1 \mu \mathrm{l}$ of DNA template, $0.2 \mu \mathrm{l}$ of Taq DNA polymerase $(5 \mathrm{U} / \mu \mathrm{l})$, and $18.3 \mu \mathrm{l}$ of $\mathrm{H}_{2} \mathrm{O}$. Amplification was conducted in an

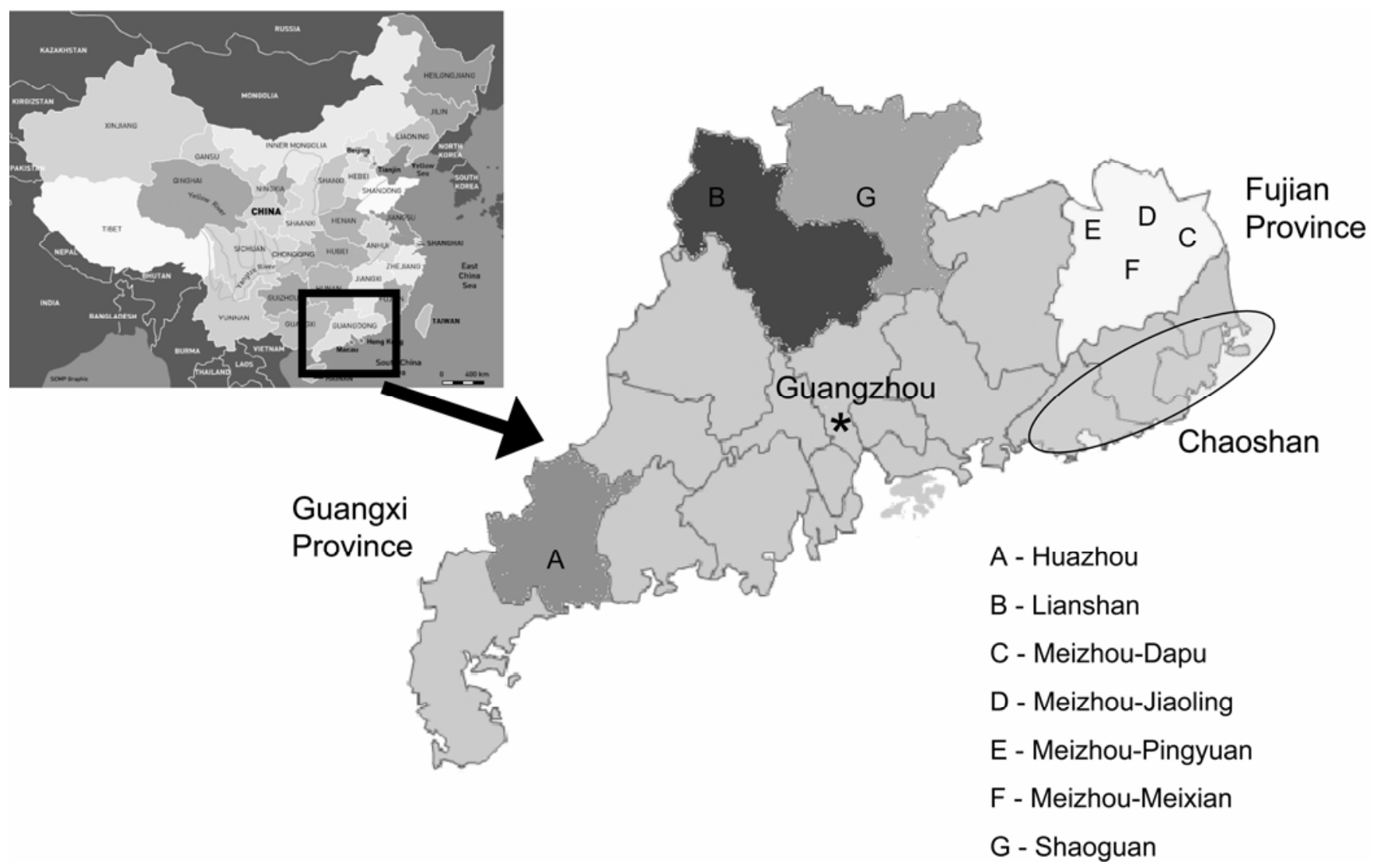

Fig. 1. Geographical locations in Guangdong Province of the People's Republic of China, where citrus Huanglongbing samples were collected for this study. Arrow indicates expanded map of Guangdong province, which is framed in the smaller inset of the national map. 
MJ Research Tatrad DNA Engine 2 with an initial denaturation at $96^{\circ} \mathrm{C}$ for $10 \mathrm{~min}$, followed by 30 cycles of denaturation at $96^{\circ} \mathrm{C}$ for $30 \mathrm{~s}$, annealing at $55^{\circ} \mathrm{C}$ for $30 \mathrm{~s}$, and extension at $72^{\circ} \mathrm{C}$ for $30 \mathrm{~s}$.

For performing nested PCR to amplify DNA from the $16 \mathrm{~S}$ rDNA locus, the procedure of Deng et al. (9) was followed. The first round of was the same as above but used primer set $\mathrm{fDl} / \mathrm{rD} 1$ (Table 1) and 10 cycles of PCR. Amplicon $(2 \mu \mathrm{l})$ then was used as template for the second round of PCR using primer set OI1/OI2c with either of the two protocols described above. The amplified DNAs were resolved by electrophoresis in $1.5 \%$ agarose gels and visualized by ethidium bromide staining.

DNA sequence analyses. Selected PCR amplicons (Table 2) were cloned in plasmid pMD18-T and sequenced (Shanghai Bioasia Biology and Technology Company, Shanghai, PRC) or amplicons were sequenced directly with a 3130xl Genetic Analyzer (Applied Biosystem, Foster City, CA). DNA fragments were sequenced from both directions to check for accuracy. DNA sequences were compared with the current GenBank database using the BLASTn network service available in the National Center for Biotechnology Information. The current version of GenBank database includes 23 16S rDNA sequences, $11 \beta$-operon sequences, and six omp gene sequences for $\mathrm{Ca}$. Liberibacter spp. Multiple sequence alignments were performed using the Query-anchored with identities option within the BLASTn tool or using
CLUSTAL W (25). Single nucleotide polymorphisms (SNPs) were used to describe bacterial population diversity.

\section{RESULTS}

Characteristic leaf symptoms of HLB in pummelo are mottling (Fig. 2A) and chlorosis (Fig. 2B). As the disease progresses, new leaves are small, upright, and show a variety of chlorotic patterns (Fig. 2C and D). Patchy yellowing of infected trees in an orchard could be viewed from a distance (Fig. 2E). Extensive defoliation of infected trees or branches and limb dieback of severely affected trees also was observed. In general, fruit from infected trees was smaller than normal; internally, the central axis was skewed to one side and the pulp tasted sour (data not shown). At the Lianshan site, $80 \%$ of 1,200 individual Shatianyou pummelo trees showed leaf mottling or yellowing symptoms characteristic of HLB (Fig. 2A-E).

Both PCR protocols (PRC and United States) produced the same results using the same set of positive and negative controls. PCR analyses of pummelo samples from the six locations are summarized in Table 2. Although DNA band intensity varied between samples, primer set OI1/OI2c generated an approximately 1,100-bp DNA band from samples from Meixian (lanes 19 and 12), Jiaoling (lanes 1-3 and 6-8), and Dapu (all lanes) (Fig. 3). For samples which amplified weakly with the standard PCR procedures, nested PCR was used to increase amplicon concentration for re- striction endonuclease digestion analysis. $X b a \mathrm{I}$ restriction endonuclease digestion of amplicons produced two DNA fragments of approximately 500 and 600 bp (Fig. 4), suggesting the presence of ' $\mathrm{Ca}$. Liberibacter asiaticus' (16). This conclusion was supported further by the PCR results from primer set A2/J5, where a DNA fragment of approximately $700 \mathrm{bp}$ was amplified (data not shown). The same results were obtained from known HLB-affected sweet orange trees and seven of eight symptomatic sweet orange trees in Pingyuan (Fig. 3). As expected, all negative controls (lanes water, Dixon, and Teme) showed no amplified products. Primer set OA1/OI2c produced results similar to those obtained with the OI1/OI2c primer pair but with a slightly lower PCR amplification frequency (Table 2). No amplifications specific to ' $\mathrm{Ca}$. Liberibacter americanus' were detected from any of the samples using primer set GB1/GB2 (data not shown).

All three cloned sequences from the $16 \mathrm{~S}$ rDNA locus amplified with primer pair OI1/OI2c were identical to one another. Similarly, the three cloned sequences derived from the $r p l A / J$ locus with primer pair A2/J5 were identical to one another, as were the five cloned sequences derived from the omp locus with the Omp1218f/Omp2026r primer pair (data not shown). Representative sequences from each locus have been deposited in GenBank with the accession numbers DQ303210, DQ303211, and EF580135.

Table 1. List of sequences, targeted genomic loci, and strain specificity of primers used to study Candidatus Liberibacter in pummelo

\begin{tabular}{|c|c|c|c|c|c|}
\hline Primer set & Primer sequence $\left(5^{\prime}-3^{\prime}\right)$ (forward/reverse) & $\begin{array}{c}\text { Genomic } \\
\text { locus }\end{array}$ & $\begin{array}{l}\text { Amplicon } \\
\text { size (bp) }\end{array}$ & Specificity & $\begin{array}{l}\text { XbaI profile } \\
\text { (bp) }\end{array}$ \\
\hline $\mathrm{OI} 1 / \mathrm{OI} 2 \mathrm{c}$ & $\begin{array}{l}\text { GCG CGT ATG CAA TAC GAG CGG CA/ } \\
\text { GCC TCG CGA CTT CGC AAC CCA T }\end{array}$ & $16 \mathrm{~S}$ rDNA & 1,160 & $\begin{array}{l}\text { 'Ca. L. asiaticus' } \\
\text { ('Ca. L. africanus') }\end{array}$ & $\begin{array}{l}640,520 \\
(520,506,130)\end{array}$ \\
\hline $\mathrm{OA} 1 / \mathrm{OI} 2 \mathrm{c}$ & $\begin{array}{l}\text { GCG CGT ATT TTA TAC GAG CGG CA/ } \\
\text { GCC TCG CGA CTT CGC AAC CCA T }\end{array}$ & $16 \mathrm{~S}$ rDNA & 1,160 & $\begin{array}{l}\text { 'Ca. L. africanus' } \\
\text { ('Ca. L. asiaticus') }\end{array}$ & $\begin{array}{l}520,506,130 \\
(640,520)\end{array}$ \\
\hline GB1/GB1 & $\begin{array}{l}\text { AAG TCG AGC GAG TAC GCA AGT ACT/ } \\
\text { CCA ACT TAA TGA TGG CAA ATA TAG }\end{array}$ & $16 \mathrm{~S}$ rDNA & 1,027 & 'Ca. L. americanus' & Not applied \\
\hline $\mathrm{A} 2 / \mathrm{J} 5$ & $\begin{array}{l}\text { TAT AAA GGT TGA CCT TTC GAG TTT/ } \\
\text { ACA AAA GCA GAA ATA GCA CGA ACA A } \\
\ldots\end{array}$ & $\begin{array}{l}r p l \mathrm{~A} / \mathrm{J} \\
\ldots\end{array}$ & $\begin{array}{l}703 \\
669\end{array}$ & $\begin{array}{l}\text { 'Ca. L. asiaticus' } \\
\text { 'Ca. L. africanus' }\end{array}$ & $\begin{array}{l}\text { Not applied } \\
\ldots\end{array}$ \\
\hline Omp1218f/Omp2026r & $\begin{array}{l}\text { TAT CAT GGC CAC GGG TTA TT/ } \\
\text { CAC GCG GAC CTA TAC CCT TA }\end{array}$ & omp & 809 & 'Ca. L. asiaticus' & Not applied \\
\hline $\mathrm{fDl} / \mathrm{rD} 1$ & $\begin{array}{l}\text { AGA GTT TGA TCC TGG CTC AG/ } \\
\text { AAG GAG GTG ATC CAG CC }\end{array}$ & $16 \mathrm{~S}$ rDNA & $\approx 1,500$ & Bacteria & Not applied \\
\hline
\end{tabular}

Table 2. Standard polymerase chain reaction (PCR) detection of Candidatus Liberibacter spp. from symptomatic leaves of pummelo and sweet orange from different locations in Guangdong Province, People's Republic of China

\begin{tabular}{|c|c|c|c|c|c|c|c|c|}
\hline \multirow[b]{2}{*}{ Location } & \multirow[b]{2}{*}{ Total $^{\text {b }}$} & \multicolumn{5}{|c|}{ PCR positives with indicated primer sets ${ }^{a}$} & \multirow[b]{2}{*}{ Cultivar } & \multirow[b]{2}{*}{ Species } \\
\hline & & OI1-OI2c & OA1-OI2c & GB1-GB3 & A2-J5 & Omp1218f-Omp2026r & & \\
\hline Huazhou & 4 & 4 & 4 & 0 & 4 & $4(1)$ & Juhong & Citrus grandis \\
\hline Lianshan & 50 & $40(1)$ & NT & NT & $42(1)$ & NT & Shatianyou & C. grandis \\
\hline Shaoguan & 6 & 6 & NT & NT & 6 & NT & Shatianyou & C. grandis \\
\hline Meizhou-Meixian & 12 & $9(1)$ & 6 & 0 & $9(1)$ & $9(1)$ & Shatianyou & C. grandis \\
\hline Meizhou-Dapu & 4 & $4(1)$ & 4 & 0 & $4(1)$ & $4(1)$ & Shatianyou & C. grandis \\
\hline Meizhou-Jiaoling & 8 & 6 & 3 & 0 & 7 & $7(1)$ & Shatianyou & C. grandis \\
\hline Meizhou-Pingyuan & 8 & 7 & 6 & 0 & 7 & $7(1)$ & Navel orange & C. sinensis \\
\hline
\end{tabular}

a Primer sets OI1-OI2c and OA1-OI2c are specific to both ' $\mathrm{Ca}$. L. asiaticus' and ' $\mathrm{Ca}$. L. africanus'; and primer set GB1-GB3 is specific to ' $\mathrm{Ca}$. L. americanus'. NT = not tested. Numbers in parentheses are amplicons with nucleotide sequence determined.

b Total number of samples. 
For the 16S rDNA, DQ303210 shared 99.8 to $100.0,97.5$ to 98.5 , and $96.6 \%$ identity to ' $\mathrm{Ca}$. Liberibacter asiaticus', ' $\mathrm{Ca}$. Liberibacter africanus' sequences, and ' $\mathrm{Ca}$. Liberibacter americanus' sequences, respectively. For the rplA-J locus of the $\beta$ operon, DQ303211 shared 99.8 to 100 and 78.4 to $80.1 \%$ identity with ' $\mathrm{Ca}$. Liberibacter asiaticus' and ' $C a$. Liberibacter africanus' sequences, respectively. No $\beta$ operon sequence from ' $\mathrm{Ca}$. Liberibacter americanus' was available for comparison. For the omp gene, EF580135 showed 99.7 to $100 \%$ similarity to ' $\mathrm{Ca}$. Liberibacter asiaticus' sequences and $70 \%$ to ' $\mathrm{Ca}$. Liberibacter africanus' sequences. SNPs at the omp locus among the different strains of ' $\mathrm{Ca}$. Liberibacter asiaticus' are shown in Table 3. Based on the SNPs, the Meizhou pummelo strains grouped with the NakhomPathom (Thailand) and Pokhara (Nepal) strains and a strain from an unspecified location in China; however, the Meizhou strains were distinct from the Lipacity (Philippines) and Behai (China) strains.

\section{DISCUSSION}

HLB in pummelo was reported more than half a century ago in China and the disease severity was described as light
(19). Later observations reported that symptoms of HLB in pummelo were less severe $(4,5)$. Our observations show that symptoms of HLB in pummelo can be

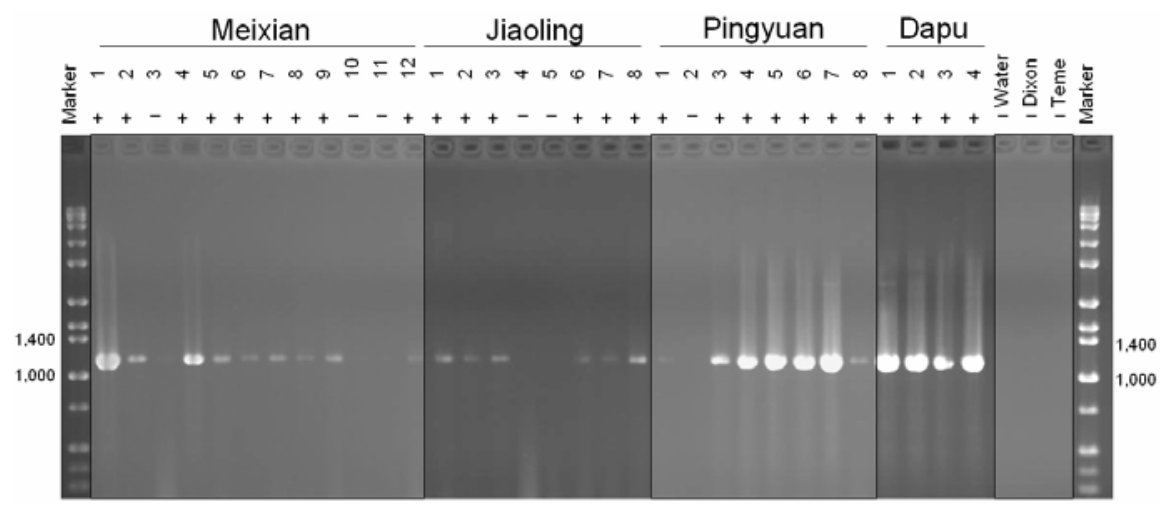

Fig. 3. Agarose gel analysis of reaction products for detection of Huanglongbing (HLB) pathogen 'Candidatus Liberibacter asiaticus' in Shatianyou pummelo leaf samples using standard polymerase chain reaction with primer set OI1/OI2c. Top line indicates sample origin in Guangdong Province and individual samples are indicated by sequential numbers in the second line. Interpretations of amplification results indicating presence (+) or absence (-) of the HLB bacterium is indicated in the third line. Indicated controls are as described in the text. Sizes of representative DNA markers (bp) are indicated in the outer lanes.

B

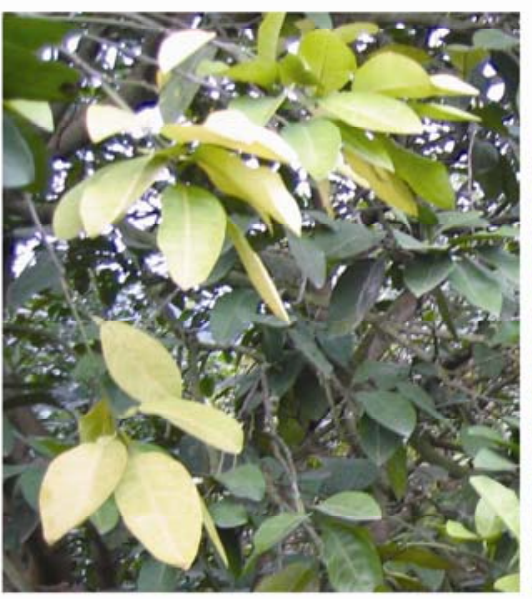

C

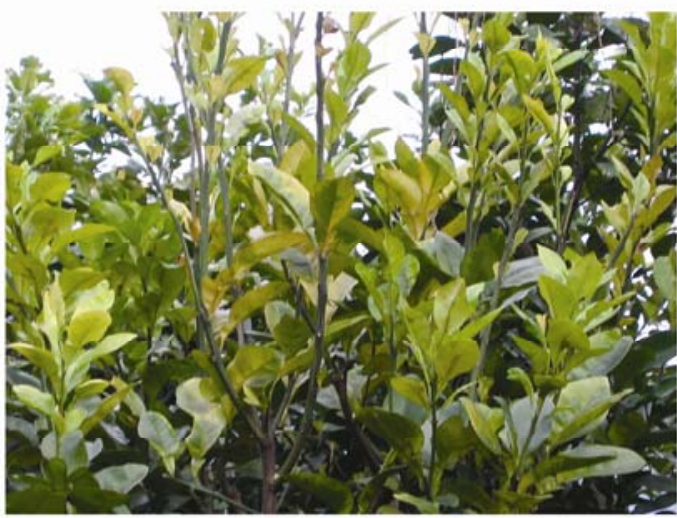

\section{A}

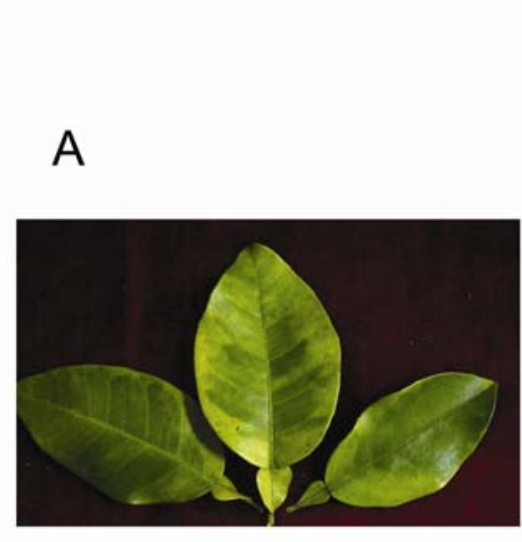

\section{A}

D
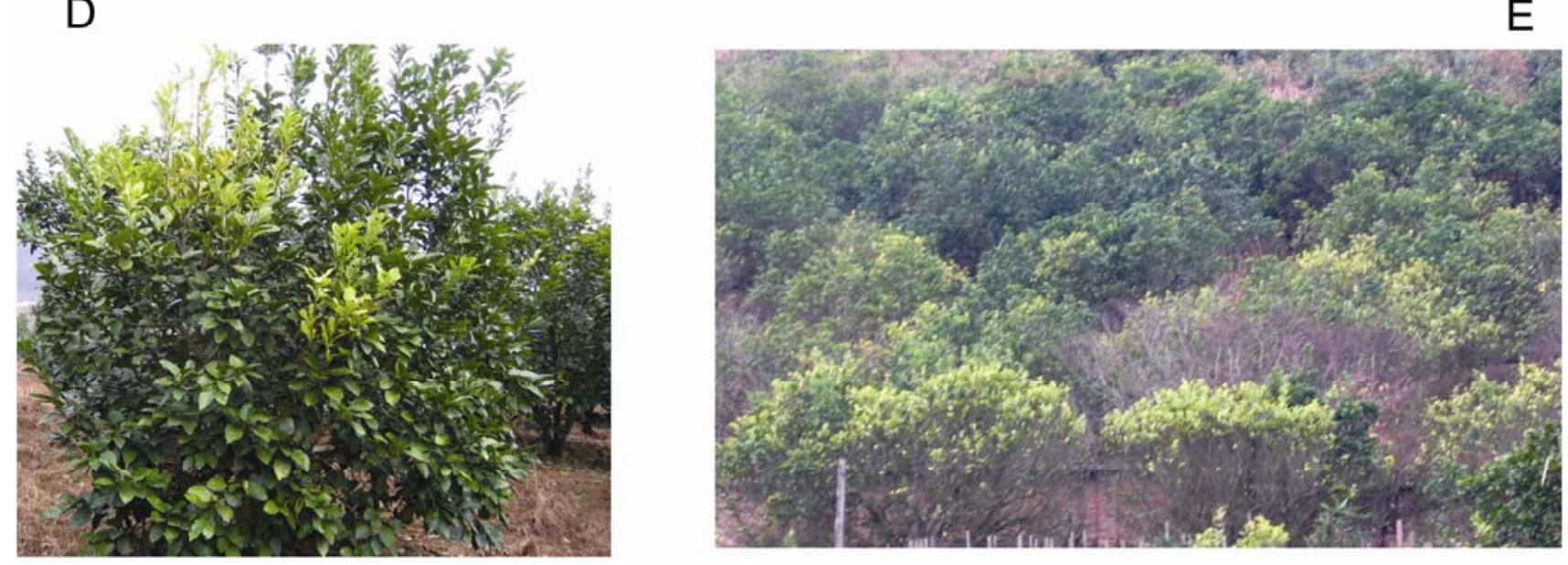

Fig. 2. Foliar symptoms of Huanglongbing on Shatianyou pummelo. A, Leaf mottling; B, leaf yellowing; C, leaf yellowing and mottling of young shoots; $\mathbf{D}$, yellow shoots; and E, a distant view of a Shatianyou pummelo orchard with leaf mottling symptoms and yellow shoots characteristic of Huanglongbing disease. 
severe and infection can reach a high incidence (about $80 \%$ ) in field situations. Thus HLB in pummelo potentially can be as destructive as it is in sweet orange and mandarin. The reason for the differences between our observations of a higher incidence and greater severity of symptoms than those reported previously $(4,5,19)$ is unknown. Possible explanations for these different observations include cultivar differences between previous and current plantings and variation in the pathogenicity of $C a$. Liberibacter strains.

Both leaf mottling and yellow shoots are characteristic symptoms of HLB in pummelo, as was described in previous reports $(10,19)$. Data from this study showed $>80 \%$ correlation between symptomatology and detection of the pathogen with standard PCR, supporting the use of symptomatology for quick presumptive HLB diagnosis. Diagnosis of HLB through symptomatology by an experienced professional remains an effective and efficient practice (2). This is particularly true for regions like southern China, where HLB has a historical presence and is firmly established.
However, when the occurrence of HLB is suspected in new areas, pathogen identification is required for confirmation of the diagnosis by visual symptoms to avoid the misidentification of physiological disorders such as zinc deficiency as HLB. Because $C a$. Liberibacter has not been cultured in an artificial medium, DNA-based detection methods are the best alternative. It also should be noted that, for $\mathrm{Ca}$. Liberibacter, the definition of the species was established based largely on the characteristics of $16 \mathrm{~S}$ rDNA $(15,21,22)$. The identification of $C a$. Liberibacter spp. from an HLB sample always should be based on analysis of the $16 \mathrm{~S}$ rDNA locus. Primer set OI1/OI2c amplifies the signature sequence for ' $\mathrm{Ca}$. Liberibacter asiaticus' and should be used for the species determination. Our data corroborate the results of previous studies (6-8) in that HLB in pummelo is associated with ' $\mathrm{Ca}$. Liberibacter asiaticus', validating the procedures using the currently available $\mathrm{Ca}$. Liberibacter sp. genomic information for diagnosis of HLB in China.

Detection sensitivity varied between samples and locations and we attribute this
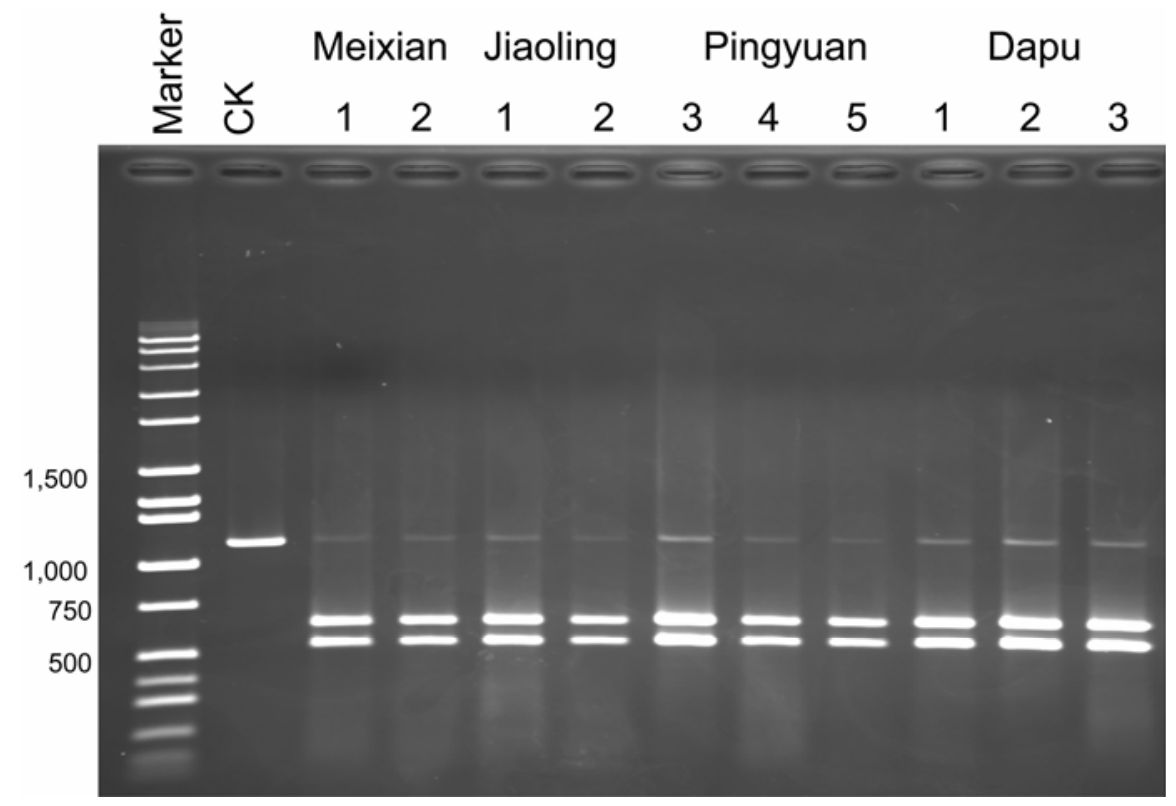

Fig. 4. Agarose gel electrophoresis of $\mathrm{XbaI}$ restriction endonuclease digestion of representative amplicons amplified from Huanglongbing-infected pummelo samples using nested polymerase chain reaction with primary primer set $\mathrm{OI} 1 / \mathrm{OI} 2 \mathrm{c}$ and secondary set $\mathrm{fDl} / \mathrm{rD} 1$. Top line indicates sample origin in Guangdong Province and individual samples are indicated by numbers in the second line. CK is undigested amplified DNA as a control. Incompletely digested amplified DNA which co-migrates with the CK control is seen as a faint DNA band in all sample lanes. Left-most lane contains DNA markers with specific DNA marker sizes (bp) indicated. variation to differences in bacterial titer. However, test results from multiple symptomatic samples indicated that the standard PCR procedure was satisfactory for detection and confirmation of ' $\mathrm{Ca}$. Liberibacter asiaticus'. To increase detection sensitivity, nested PCR is helpful (9). As noted previously (9) and demonstrated in this study, nested PCR helped to increase amplicon concentration for the $\mathrm{XbaI}$ restriction endonuclease analysis that is needed for differentiation of ' $\mathrm{Ca}$. Liberibacter asiaticus' from ' $C a$. Liberibacter africanus' when pathogen titer is low.

We are not aware of any previous analyses of multiple samples for detection of $\mathrm{Ca}$. Liberibacter in pummelo. In this study, we collected samples from six locations in Guangdong Province. We specifically examined the discriminatory omp locus (1) and concluded that all ' $\mathrm{Ca}$. Liberibacter asiaticus' strains characterized from pummelo in Guangdong were identical. The genetic homogeneity of pummelo strains of ' $C a$. Liberibacter asiaticus' found in this study suggests that spread of the bacterium into pummelo either by vectors or by infected propagation material is a recent occurrence. This agrees with the cultivation history of pummelo in Guangdong, where a large acreage of pummelo (cv. Shatianyou) was grown in Meizhou only after the early 1990 s to develop the nation's major production base of Shatianyou. Establishment of this acreage was followed by an outbreak of HLB (10), and the ' $\mathrm{Ca}$. Liberibacter asiaticus' strains characterized from pummelo trees in this production area were genetically identical to ' $\mathrm{Ca}$. Liberibacter asiaticus' strains from sweet orange from both the same region (Pingyuan) and the nearby region of Chaoshan (data not shown). The close geographical proximity of these sources suggests that the current ' $\mathrm{Ca}$. Liberibacter asiaticus' in pummelo in Meizhou may have its origin in Chaoshan.

It is of global epidemiological importance to analyze strains of ' $\mathrm{Ca}$. Liberibacter asiaticus' from different regions and hosts around the world to elucidate the pattern of spread of the HLB pathogen. Based on single strains from different geographical locations (except for two Indian strains), Bastianel et al. (1) differentiated 10 ' $\mathrm{Ca}$. Liberibacter asiaticus' strains into nine RFLP groups using the omp gene. We examined the omp gene region and found that multiple pummelo strains in Guang-

Table 3. Single nucleotide polymorphisms (SNPs) in outer membrane protein (omp) gene sequences of 'Candidatus Liberibacter asiaticus' strains

\begin{tabular}{|c|c|c|c|c|c|c|}
\hline \multirow{2}{*}{$\begin{array}{l}\text { GenBank accession } \\
\text { EF580135 }\end{array}$} & \multirow{2}{*}{$\begin{array}{r}\text { Strain } \\
\text { Meizhou }^{\mathrm{a}}\end{array}$} & \multicolumn{4}{|c|}{ SNP and position within sequenced fragment } & \multirow{2}{*}{$\begin{array}{c}\text { Country of origin } \\
\text { China }\end{array}$} \\
\hline & & C 149 & T 379 & A 394 & C 406 & \\
\hline AY842432 & NakhomPathom & C 1422 & $\mathrm{~T} 1652$ & A 1677 & C 1679 & Thailand \\
\hline AY 842430 & Pokhara & C 1422 & T 1652 & A 1677 & C 1679 & Nepal \\
\hline AY642159-LAS & Not specified & C 1935 & T 2165 & A 2180 & C 2192 & China \\
\hline AY842431 & Lipacity & $\mathrm{T} 1422$ & C 1652 & A 1677 & C 1679 & Philippines \\
\hline AY842429 & Behai & C 1422 & T 1652 & G 1677 & T 1679 & China \\
\hline
\end{tabular}

a Representing four additional identical sequences from Guangdong Province, People's Republic of China. 
dong grouped with the ' $\mathrm{Ca}$. Liberibacter asiaticus' strains from Thailand, Nepal, and an unspecified location in China (1) but were different from strains from the Philippines and Behai (China) based on two polymorphic sites. However, to provide a more critical analysis of strain diversity, studies of more strains from both Behai and the Philippines and of more genomic loci are needed. Identity between ' $\mathrm{Ca}$. Liberibacter asiaticus' and ' $\mathrm{Ca}$. Liberibacter africanus' is $70.0 \%$ at the $\mathrm{omp}$ locus, $78.4 \%$ at the rplA-J locus, and $97.5 \%$ at $16 \mathrm{~S}$ rDNA region, suggesting that, among the three known genomic loci, omp has the best potential for use in HLB epidemiology research.

Sequence analysis showed that none of the four SNPs in omp cause premature termination of translation of the encoded peptide but do cause variations in amino acids. All these SNPs are located in the DNA region coding for a highly conserved peptide domain exposed on the bacterial surface. Variable surface proteins could serve as antigens to develop specific antibodies for serological detection and differentiation of HLB populations. It was reported that monoclonal antibodies could differentiate $\mathrm{Ca}$. Liberibacter strains from different origins $(2,12)$, although the identity of the specific antigens remains unknown.

In summary, we identified and characterized HLB bacteria from pummelo gathered from six locations in Guangdong, China. Association of leaf and tree symptoms with PCR detection of HLB in these samples was $>80 \%$. Based on the SNP diversity in the omp sequence, the pummelo ' $C a$. Liberibacter asiaticus' strains in Guangdong are homogenous. The Guangdong pummelo strains are grouped with strains from Thailand, Nepal, and an unspecified location in China but separated from strains from the Philippines and China-Behai.

\section{ACKNOWLEDGMENTS}

Part of this research was supported by Guangdong Provincial Foundation of Natural Sciences (032262) and a Guangdong Provincial Research Grant for Science and Technology (2004B20901010).
LITERATURE CITED

1. Bastianel, C., Garnier-Semancik, M., Renaudin, J., Bove, J. M., and Eveillard, S. 2005. Diversity of "Candidatus Liberibacter asiaticus" based on the omp gene sequence. Appl. Environ. Microbiol. 71:6473-6478.

2. Bove, J. M. 2006. Huanglongbing: a destructive, newly-emerging, century-old disease of citrus. J. Plant Pathol. 88:7-37.

3. Coletta-Filho, H. D., Takita, M. A., Targon, M. L. P. N., and Machado, M. A. 2005. Analysis of 16S rDNA sequences from citrus Huanglongbing bacteria reveal a different " $\mathrm{Ca}$. Liberibacter" strain associated with citrus disease in Sao Paulo. Plant Dis. 89:848-852.

4. da Graca, J. V. 1991. Citrus greening disease. Annu. Rev. Phytopathol. 29:109-136.

5. da Graca, J. V., and Korsten, L. 2004. Citrus Huanglongbing: review, present status and future strategies. Pages 229-245 in: Diseases of Fruits and Vegetables. Vol.1. I. S. A. M. H. Naqvi, ed. Kluwer Academic Publishers, Dordrecht, The Netherlands.

6. Deng, X., Liang, Z., and Tang, W. 1999. Studies on the rapid detection of citrus Huanglongbing pathogen. J. South China Agric. Univ. 20:1-4.

7. Deng, X., and Tang, W. 1996. The studies on detection of citrus Huanglongbing pathogen by polymerase chain reaction. J. South China Agric. Univ. 17:119-120.

8. Deng, X., and Tang, W. 1998. Application of polymerase chain reaction to the detection of citrus Huanglongbing pathogen. J. Zhejiang Agric. Univ. 24:5571-5562.

9. Deng, X., Zhou, G., Li, H., Chen, J., and Civerolo, E. 2007. Detection of Candidatus Liberibacter asiaticus from Wampee (Clausena lansium Skeels) by nested PCR. Plant Health Progress doi:10.1094.

10. Deng, J., Zhong, Z., Wu, k., Luo, Z., Huang, M., Huang, X., and Hou, Z. 1995. Investigation of the cause of Shatianyou yellowing in Meizhou. China Citrus 24:26-27.

11. Florida Department of Agriculture and Consumer Service. 2005. U.S. Department of Agriculture and Florida Department of Agriculture confirm detection of citrus greening. Department Press Release 09-02-2005.

12. Garnier, M., Gao, S. J., He, Y. L., Villechanoux, S., Gandar, J., and Bove, J. M. 1991. Study of the greening organism (GO) with monoclonal antibodies: serological identification, morphology, serotypes and purification of the GO. Pages 428-435 in: Proc. Conf. Int. Organ. of Citrus Virol. 11th. IOCV, Riverside, CA.

13. Garnier, M., Jagoueix-Eveillard, S., Cronje, P. R., Le Roux, H. F., and Bove, J. M. 2000. Genomic characterization of a Liberibacter present in an ornamental rutaceous tree, Calodendrum capense, in the Western Cape Province of South Africa. Proposal of 'Candidatus
Liberibacter africanus subsp. capensis.' Int. J. Syst. Evol. Microbiol. 50:2119-2125.

14. Hocquellet, A., Toorawa, P., Bove, J. M., and Garnier, M. 1999. Detection and identification of the two Candidatus Liberobacter species associated with citrus huanglongbing by PCR amplification of ribosomal protein genes of the beta operon. Mol. Cell. Probes 13:373-379.

15. Jagoueix, S., Bove, J. M., and Garnier, M. 1994. The phloem-limited bacterium of greening disease of citrus is a member of the alpha subdivision of the Proteobacteria. Int. J. Syst. Bacteriol. 44:379-386.

16. Jagoueix, S., Bove, J. M., and Garnier, M. 1996. PCR detection of the two 'Candidatus' Liberobacter species associated with greening disease of citrus. Mol. Cell. Probes 10:43-50.

17. Kong, W., Deng, X., Liang, Z., and Tang, W. 2000. Cloning and sequence analysis of DNA fragments from the causal agent of citrus Huanglongbing. Acta Phytopathol. Sin. 30:7175.

18. Liao, X. L., Zhu, S. F., Zhao, W. J., Luo, K., Qi, Y. X., Chen, H. Y., He, K., and Zhu, X. X. 2004. Cloning and sequencing of citrus Huanglongbing pathogen 16S rDNA and its detection by real-time fluorescent PCR. J. Agric. Biotechnol. 12:80-85.

19. Lin, K.-H. 1956. Observations on yellow shoot of citrus. Acta Phytopathol. Sin. 2:1-11.

20. Murray, M. G., and Thompson, W. F. 1980. Rapid isolation of high molecular weight plant DNA. Nucleic Acids Res. 8:4321-4324.

21. Murray, R. G. E., and Schleifer, K. H. 1994. Taxonomic notes: a proposal for recording the properties of putative taxa of prokaryotes. Int J. Syst. Bacteriol. 44:174-176.

22. Murray, R. G. E., and Stackebrandt, E. 1995. Taxonomic note: implementation of the provisional status Candidatus for incompletely described procaryotes. Int. J. Syst. Bacteriol. 45:186-187.

23. Teixeira, D. C., Luc Danet, J., Eveillard, S., Cristina Martins, E., de Jesus Junior, W. C., Takao Yamamoto, P., Aparecido Lopes, S., Beozzo Bassanezi, R., Juliano Ayres, A., Saillard, C., and Bove, J. M. 2005. Citrus huanglongbing in Sao Paulo State, Brazil: PCR detection of the 'Candidatus' Liberibacter species associated with the disease. Mol. Cell Probes 19:173-179.

24. Teixeira, D., Saillard, C., Eveillard, S., Danet, J. L., da Costa, P. I., Ayres, A. J., and Bove, J. 2005. 'Candidatus Liberibacter americanus,' associated with citrus huanglongbing (greening disease) in Sao Paulo State, Brazil. Int. J. Syst. Evol. Microbiol. 55:1857-1862.

25. Thompson, J. D., Higgins, D. G., and Gibson, T. J. 1994. CLUSTAL W: improving the sensitivity of progressive multiple sequence alignment through sequence weighting, positionspecific gap penalties and weight matrix choice. Nucleic Acids Res. 22:4673-4680. 